Research Article

\title{
Biodegradable Films from Phytosynthesized TiO 2 Nanoparticles and Nanofungal Chitosan as Probable Nanofertilizers
}

\author{
Mohamed E. EL-Hefnawy $\mathbb{i D}^{1,2}$ \\ ${ }^{1}$ Department of Chemistry, Rabigh College of Science and Arts, King Abdulaziz University, Rabigh 21911, Saudi Arabia \\ ${ }^{2}$ Department of Chemistry, Faculty of Science, Tanta University, Tanta 31527, Egypt
}

Correspondence should be addressed to Mohamed E. EL-Hefnawy; drmhefnawy723@gmail.com

Received 4 July 2020; Revised 7 August 2020; Accepted 25 August 2020; Published 7 September 2020

Academic Editor: Ehsan N. Zare

Copyright (C) 2020 Mohamed E. EL-Hefnawy. This is an open access article distributed under the Creative Commons Attribution License, which permits unrestricted use, distribution, and reproduction in any medium, provided the original work is properly cited.

\begin{abstract}
Titanium dioxide nanoparticles $\left(\mathrm{TiO}_{2}\right.$-NPs) have great importance for plant nutrition and growth, at little concentrations. The bioactive polymer chitosan and its NPs provide outstanding characteristics for capping and enhancements of nanometals. The phytosynthesis of $\mathrm{TiO}_{2}$-NPswas promisingly achieved using an extract of pomegranate rind, whereas the fungal chitosan (FCt) was produced from Aspergillus brasiliensis biomass and was transformed to nanoform. The phytosynthesis of $\mathrm{TiO}_{2}-\mathrm{NPs}_{\mathrm{s}}$ generated homogenous spherical particles with 13 to $64 \mathrm{~nm}$ range and $37 \mathrm{~nm}$ mean size. The extracted FCt had $92 \%$ deacetylation degree and a molecular weight of $28,400 \mathrm{Da}$. The infrared spectral analysis of $\mathrm{TiO}_{2}-\mathrm{NPs}$, FCt-NPs, and their nanocomposite indicated their functional groups and biochemical interactions. The released amounts of $\mathrm{TiO}_{2}-\mathrm{NPs}_{\mathrm{s}}$ from their nanocomposite with FCt-NPs were $31 \%$ and $50 \%$ after the first and third hour, respectively. The nanocomposite film had a faster hydrodegradability rate which resulted from $\mathrm{TiO}_{2}-\mathrm{NP}$ addition. Therefore, the fabricated nanocomposite from $\mathrm{FCt} / \mathrm{TiO} 2_{2}$ NPs could have elevated potentiality for application as liquid spray for foliar feeding or as powder for soil amendment.
\end{abstract}

\section{Introduction}

Titanium (Ti) element has important biological consequence for plants, being advantageous at lower concentrations and potentially toxic at higher ones, but with miniature toxicity toward animals or human [1]. Whereas $\mathrm{TiO}_{2}$ antimicrobial potentiality was reported against many microorganisms $[2,3]$, it has many beneficial consequences for plant physiological attributes, especially at little dosages (the Ti contents in plant dry weight ranged from 1 to $1000 \mathrm{mg} / \mathrm{kg}$ with profitable application range of up to $100 \mathrm{mg} / \mathrm{L}$ ), including their elemental contents, biomass yield, chlorophyll contents, and foliar growth [4-6].

Nanofertilizers emerged as promising candidates for enhancing micronutrients' uptake efficiency; their successful practical applications promoted the search for more systems to improve their delivery, e.g., nanocarriers and nanocom- posites $[7,8]$. Formulated nanofertilizers could have slower release of nutrients, which improves their usage, solubility, bioavailability, and dispersion [7]. Compared to traditional fertilizers, nanofertilizers could be absorbed by crops easily, with sustained nutrient delivery into soil/plant [8].

While numerous metals/metal oxide NPs were effectually applied in plant-related sciences (including $\mathrm{TiO}_{2}, \mathrm{ZnO}$, $\mathrm{AgNO}_{3}, \mathrm{Fe}_{3} \mathrm{O}_{4}$, and $\mathrm{CeO}_{2}$ ), $\mathrm{TiO}_{2}$-NPs represented the most frequently applied nanometals in agricultural investigations $[5,9]$.

The practical exogenous applications of $\mathrm{TiO}_{2}-\mathrm{NPs}$ in crop propagation indicated their efficacy for enhancing plant performance, biomass production, photo-reduction activities, and nitrogen assimilation $[10,11]$. Moreover, these micronutrient NPs could protect chloroplast membranes from reactive oxygen species (ROS) attacking and destruction [4]. $\mathrm{TiO}_{2}$-NPs can also improve other native nutrient 
utilization via support of beneficial microbial activities [12]. The $\mathrm{TiO}_{2}$-NPs were effectually phytosynthesized (synthesis enforced by plant derivatives) using extract of various parts of plants [13-15], which was advised for increasing the process safety, feasibility, and efficiency.

The biosynthesis (green synthesis) of nanomaterials has recently become a key method for preparation of many bioactive NPs with augmented activity and reduced toxicity during their preparation and applications; the synthesis could be enforced by NPs incorporation with numerous types of biopolymers [16-18].

Biosynthesized nanometals and nanocompounds were validated as effectual and powerful antimicrobial agents in biomedical fields and their successful applications were proved [19-21].

The extract of pomegranate rinds (PRE), as a byproduct with plenty of valuable phytochemicals and biological activities, was employed for the green phytosynthesis of many metal NPs including silver, iron, and zinc [22-24], as the PRE exhibited strong reducing capability for these metals.

Chitosan (Cts), the astonishing derived amino polysaccharide from chitin deacetylation, possesses plentiful advantageous attributes (e.g., its biosafety, biodegradability, biocompatibility, nontoxicity, and efficacious bioactivities) [25]. The extraction of Cts from different fungal biomasses was promisingly achieved [26, 27]; this fungal chitosan (FCt) had comparable or superior bioactivities than commercial Cts from crustacean shells.

The polymer NPs, particularly from Cts and FCt, are well proved for their surplus functionalities and bioactivities as nanocarriers, biochelators, antimicrobial, biosorbent, and plant protectant agents, in individual or composited forms with other bioactive compounds and nanomaterials [28-30].

The application of Cts and FCt-NPs was advised for soil and water remediation from heavy metals due to their capabilities for heavy metal chelation/adsorption [28, 29].

The incorporation of $\mathrm{TiO}_{2}$ with Cts was reported to improve the composite structural, mechanical, optical, textural, vapor barring, and thermal properties and its biodegradability [31]. These composites had also augmented antimicrobial, viscoelastic, and biocompatibility attributes [3, 32, 33].

Accordingly, the intentions from this investigation were to phytosynthesize $\mathrm{TiO}_{2}$-NPs using PRE, extract FCt from grown mycelia of Aspergillus brasiliensis and transform it to NP form, then to conjugate both NPs for augmenting their release pattern and hydrodegradability.

\section{Materials and Method}

2.1. Pomegranate Rinds' Extract (PRE) Preparation. Organic pomegranate fruits (Punica granatum L.), obtained from international markets in KSA, Jeddah, were used in study. Fruits were disinfected (using 5\% sodium hypochlorite solution) and peeled and their rinds were dried (for $50 \mathrm{~h}$ at $48 \pm 2^{\circ} \mathrm{C}$ ) and ground to 60 -mesh powder size. The PRE was prepared through powder immersion for $36 \mathrm{~h}$ in ethanol (70\%) with agitation then filtration to have the extract, which was vacuum dried at $42^{\circ} \mathrm{C}$ and resuspended in deionized water (DIW) to have $10 \%(w / v)$ concentration [34].
2.2. Phytosynthesis of $\mathrm{TiO}_{2}$ Nanoparticles. Titanium (IV) chloride $\left(\mathrm{TiCl}_{4}\right.$, Sigma-Aldrich, Saint Louis, MO; purity $\geq$ 99.9\%) was the precursor for $\mathrm{TiO}_{2}$-NP phytosynthesis.

For $\mathrm{TiO}_{2}-\mathrm{NP}$ phytosynthesis, $50 \mathrm{~mL}$ of $\mathrm{TiCl}_{4}$ solution in DIW $(95 \mathrm{mg} / \mathrm{mL})$ was mixed with equal volume of PRE with strong stirring for $60 \mathrm{~min}$ at $25 \pm 1^{\circ} \mathrm{C}$. The changing solution color to whitish-brown indicated $\mathrm{TiO}_{2}-\mathrm{NP}$ synthesis. Ammonium hydroxide solution $(0.2 \mathrm{M})$ was slowly added to NP solution under stirring at $25 \pm 1{ }^{\circ} \mathrm{C}$, until reaching alkaline $\mathrm{pH}$ of 8.0 and precipitate formation. The precipitated $\mathrm{TiO}_{2}-\mathrm{NPs}$ were collected via centrifugation (at $8600^{\circ} \mathrm{g}$ ), washed with ethanol (95\%), recentrifuged, and calcined at $470 \pm 5^{\circ} \mathrm{C}$ for $200 \mathrm{~min}$, then powdered finely.

\subsection{Preparation of Fungal Chitosan/TiO ${ }_{2}-\mathrm{NP}$ Composite.} Grown mycelia of Aspergillus brasiliensis (ATCC-16404), after aerobic propagation in broth media of potato dextrose (containing infusion of $200 \mathrm{~g}$ potato $+20 \mathrm{~g}$ dextrose/L), were used as chitosan source by extraction according to Tayel et al. [26]. Briefly, inoculated fungal conidial suspension $\left(10^{6}\right.$ spores $\left./ \mathrm{mL}\right)$, in $500 \mathrm{~mL}$ of broth medium, were incubated aerobically under stirring $(120 \mathrm{~g})$ for 6 days at $28^{\circ} \mathrm{C}$. The FCt extraction involved fungal biomass harvesting and washing with DIW, treatment with 20 folds $(v / w)$ from $1 \mathrm{M}$ of $\mathrm{NaOH}$ then $\mathrm{HCl}$ and finally deacetylation by treatment with 20 folds from $60 \%(w / v) \mathrm{NaOH}$ solution for $60 \mathrm{~min}$ at $110^{\circ} \mathrm{C}$.

The molecular weight of FCt was determined by gel permeation chromatography (GPC) with the following specifications: GPC (PN-3000), together with a refractive index detector (PN-1000) from Post-nova analytics, Eresing, Germany, was operated at $15^{\circ} \mathrm{C}$ and $90^{\circ} \mathrm{C}$. The used columns for detection were Nucleogel GFC 1000-8 (Macherey-Nagel GmbH \& Co. KG, Düren, Germany) and Gral300 by (Polymer Standards Service GmbH, Mainz, Germany). Standard pullulans (with molecular weight of 11,800, 47,300, 112,000, and 780,000) were used for calibration.

The calculation of FCt deacetylation degree (DD) was based on its infrared spectral analysis using FTIR (Fourier-transform infrared spectroscopic -FTS 45, Bio-Rad, Germany), using the absorbance ratios at A1655/A3450.2.4.

The FCt-NP synthesis employed ionotropic gelation method (based on the electrostatical interaction of positively charged FCt molecules with the negatively charged pentasodium tripolyphosphate "Na-TPP", Sigma-Aldrich, St. Louis, Mo.); FCt solution $(0.5 \% w / v)$ in $1.5 \%$ acidic solution $\left(\mathrm{CH}_{3} \mathrm{COOH}\right.$, Sigma-Aldrich) was prepared and sonicated at $50 \mathrm{~W}$ for $20 \mathrm{~min}$ (Braun-Labsonic, Germany). Equal volume from Na-TPP solution (of $0.5 \% w / v$ in DIW) was slowly dropped into stirred FCt solution, then resonicated and centrifuged (at $8400 \times g$ for $25 \mathrm{~min}$ ). The obtained FCt-NP pellet was sonicated after suspension in DIW and recentrifuged [29].

Later, $500 \mathrm{mg}$ of FCt-NPs (dissolved in $50 \mathrm{~mL}$ of $1.5 \%$ acetic acid solution) and $50 \mathrm{mg}$ from $\mathrm{TiO}_{2}$-NPs (dispersed in $5 \mathrm{~mL}$ of DIW) were combined and then sonicated for $30 \mathrm{~min}$. The uniform composite emulsion was further magnetically stirred for 250 min to enforce NP crosslinkage [3]. 


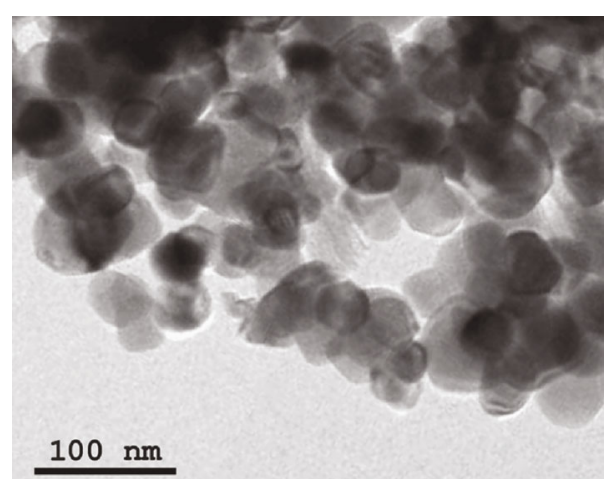

(a)

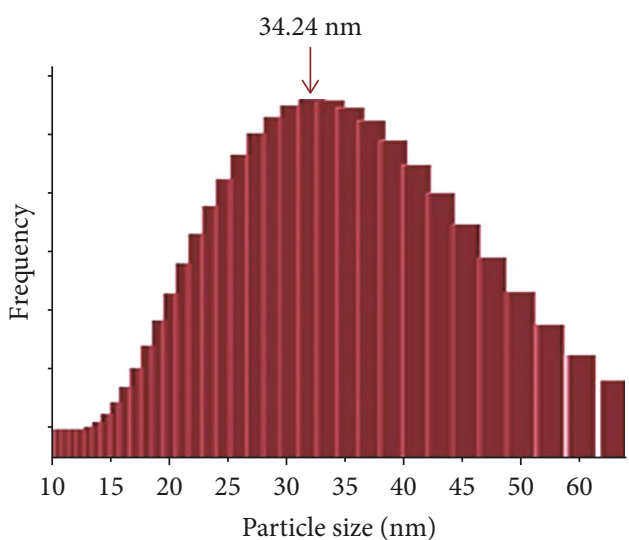

(b)

FIgure 1: Phytosynthesized $\mathrm{TiO}_{2}$ nanoparticles, indicating their morphological features using TEM (a) and particle size distribution (b).

\subsection{Characterization of Synthesized Nanoparticles. The FTIR} spectroscopy was employed for analyzing the functional groups of NPs and nanocomposite $\left(\mathrm{TiO}_{2}-\mathrm{NPs}\right.$, FCt-NPs, and $\left.\mathrm{FCt} / \mathrm{TiO}_{2}-\mathrm{NPs}\right)$ at a wavenumber range of 550 $4000 \mathrm{~cm}^{-1}$, after integration of NPs with $1 \% \mathrm{KBr}$. The $\mathrm{TiO}_{2}-\mathrm{NP}$ size distribution and charges were estimated via PCS (photon correlation spectroscopy, Malvern ${ }^{\mathrm{TM}}$ Zetasizer, Malvern, UK), and their structure was further confirmed via TEM (transmission electron microscopy; Leica ${ }^{\mathrm{TM}}$ Leo0430, Cambridge Ltd., UK). The surface morphology and appearance of the nanocomposite were screened using SEM imaging (scanning electron microscopy, JEOL JSMIT100, Tokyo, Japan).

2.5. $\mathrm{TiO}_{2}-\mathrm{NP}$ Release from FCt Nanoconjugates. The dispersed $\mathrm{TiO}_{2}$-NPs in FCt solution was ultrasonicated for $120 \mathrm{~min}$ and dispensed onto Petri plates; then, their solvent (acidified DIW, pH 5.2) was vacuum evaporated for $16 \mathrm{~h}$. The dried formed films were peeled and immersed in 50 folds $(w / v)$ from neutral DIW, which were agitated at $320 \times g$, and $10 \mathrm{~mL}$ from the supernatants was gathered for $180 \mathrm{~min}$, with $30 \mathrm{~min}$ intervals. Samples were analyzed for $\mathrm{Ti}$ content according to Korn et al. [35], involving treatment with 40 folds $(v / w)$ from concentrated hydrofluoric (50\%) and sulfuric (98\%) acids then dilution with $3 \% \mathrm{HNO}_{3}$ and ion determination using ICP (inductively coupled plasma optical emission spectrometer, OES-5110, Agilent Inc. Santa Clara, CA).The experiments were performed in triplicate and their mean values were calculated.

2.6. Hydrolytic Degradation of NPs-Based Films. The hydrolytic degradation percentage of NPs-based films (FCt-NP and $\mathrm{FCt} / \mathrm{TiO}_{2}-\mathrm{NP}$ composites) was performed in triplicate at $25 \pm 2^{\circ} \mathrm{Cfor} 10 \mathrm{~h}$, with $60 \mathrm{~min}$ intervals, using $10 \times 10 \mathrm{~mm}$ film squares. The NP films were immersed in neutral DIW, with slow stirring, for each interval time; then, they were attained via filtration to disregard DIW and dissolved materials. The residual films were vacuum dried and weighed to assess their mass loss [36].

\section{Results and Discussion}

3.1. $\mathrm{TiO}_{2}-\mathrm{NP}$ Phytosynthesis Using PRE. The $\mathrm{TiO}_{2}-\mathrm{NPs}$ could be successfully synthesized using PRE, as evidenced from their characterization (Figure 1). The phytosynthesized $\mathrm{TiO}_{2}$-NPs appeared with spherical and matched shapes with slight NP agglomerations (Figure 1(a)). The $\mathrm{TiO}_{2}-\mathrm{NP}$ size distribution ranged from 13.42 to $63.84 \mathrm{~nm}$, with $34.21 \mathrm{~nm}$ median size and $36.71 \mathrm{~nm}$ mean size (Figure $1(\mathrm{~b})$ ). The recorded Zeta potential average for these phytosynthesized $\mathrm{TiO}_{2}$-NPs was $-24.8 \mathrm{mV}$.

Numerous bioactive compounds are contained in PRE, including polyphenols, vitamins, flavonoids, esters, and protein. The polyphenols, vitamin C, and many other phytoconstituents contain extensive hydroxyl groups with strong reducing capability [22]. PRE was acknowledged to contain extraordinarily elevated phenolic compounds as natural antioxidants sources [37]. Thus, these biactive phytoconstituents are assumingly the one responsible for reducing $\mathrm{TiO}_{2}$ to their NP form.

The PPE was effectively employed for the phytosynthesis of many metal nanoparticles, e.g., silver, gold, and zinc $[22,23,38]$; this is matching with its capability forTiO ${ }_{2}^{-}$ NP synthesis in current study.

3.2. Fungal Chitosan Extraction. The chitosan was effectually extracted from A. brasiliensis mycelia; the extracted FCt had a molecular weight of $28,400 \mathrm{Da}$ with $92.1 \%$ deacetylation degree.

The successfulness of FCt extraction from A. brasiliensis confirmed foregoing investigations that reported the fungi potentialities as sustainable alternative sources for Cts production [26, 28, 29, 39]; these reports applied the extracted FCt, from varied fungal genera, in the environmental and biomedical fields.

3.3. Nanoparticle Characterization. The FTIR spectral evaluation was conducted for FCt-NPs, $\mathrm{TiO}_{2}-\mathrm{NPs}$, and their nanocomposite $\left(\mathrm{FCt} / \mathrm{TiO}_{2}-\mathrm{NPs}\right)$ to appraise their biochemical bonds and the potential interaction/crosslinkage between the synthesized NPs. For $\mathrm{TiO}_{2}-\mathrm{NP}$ spectra (Figure 2, $\mathrm{TiO}_{2}-$ 


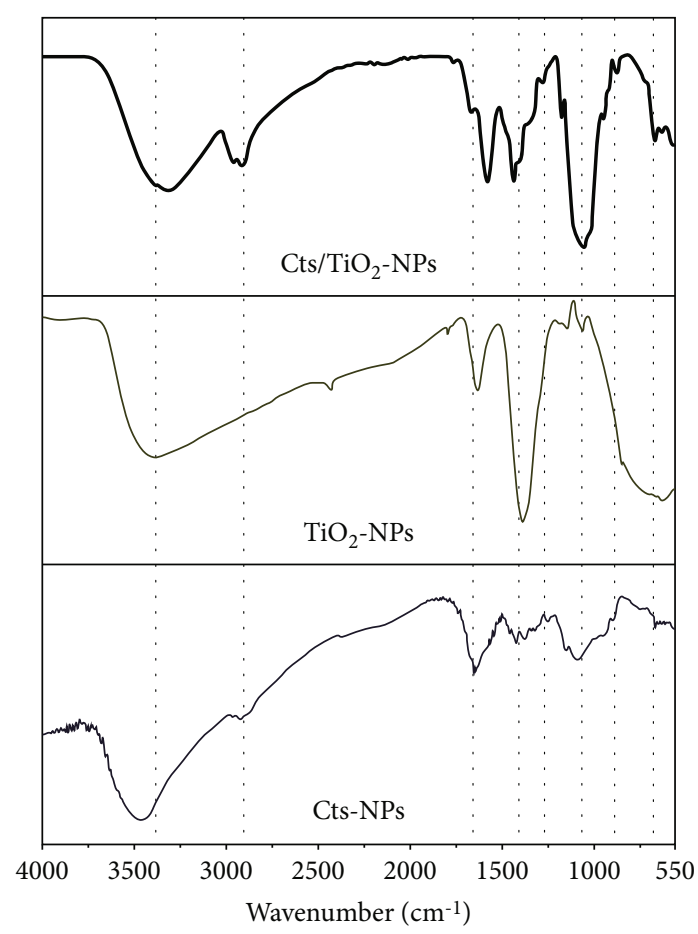

FIGURE 2: Infrared spectral analysis (FTIR) of chitosan nanoparticles (Cts-NPs), titanium dioxide nanoparticles $\left(\mathrm{TiO}_{2}\right.$ $\mathrm{NPs})$, and their composite $\left(\mathrm{Cts} / \mathrm{TiO}_{2}-\mathrm{NPs}\right)$.

NPs), the representative broad peak of $\mathrm{Ti}-\mathrm{O}-\mathrm{Ti}$ stretching was detected around $612 \mathrm{~cm}^{-1}$ wavenumber. The appeared vibrated bands at 1107 and $1120 \mathrm{~cm}^{-1}$ are specified the stretching/bending modes of $\mathrm{CH}_{3}$ and $\mathrm{Ti}-\mathrm{OH}$, respectively, of the NPs surface groups [40].

The sharp peak (at $1638 \mathrm{~cm}^{-1}$ ) and the broad peak (at $3405 \mathrm{~cm}^{-1}$ ) are mainly attributed to the NP adsorbed water and occurrence of hydroxyl groups, respectively [14]. The hydroxyl groups' presence is commonly involving the photocatalytic activity augmentations; with the increased amount of $\mathrm{OH}-$ on $\mathrm{TiO}_{2}-\mathrm{NP}$ surface, their higher electron transportability and enhanced photocatalytic activity could be assumed [41].

The appeared peak at $651 \mathrm{~cm}^{-1}$ in $\mathrm{TiO}_{2}-\mathrm{NP}$ spectrum conceivably indicated the involvement of $\mathrm{Ti}$ anatase phase in phytosynthesized NPs; this phase could be further confirmed via X-ray diffraction (XRD) analyses. Conversely, the disappearance of any peaks around $2900 \mathrm{~cm}^{-1}$, which indicates $\mathrm{C}-\mathrm{H}$ stretching, validated that subtraction of the entire PRE organic components from the $\mathrm{TiO}_{2}-\mathrm{NP}$ sample during their calcination [14].

For FCt-NP spectrum (Figure 2, Cts-NPs), the strong wide peak around $3453 \mathrm{~cm}^{-1}$ could correspond to combined $\mathrm{O}-\mathrm{H}$ stretching and hydrogen bonding; the peak wideness with increased intensity could indicate hydrogen bonding enhancement after NP synthesis [30]. The FCt-NP spectrum displayed also (at $1171 \mathrm{~cm}^{-1}$ ) a sharp indicating peak for $\mathrm{P}=\mathrm{O}$, due to crosslinkage of FCt with TPP. The main characteristic absorption peaks of FCt were detected at $1714 \mathrm{~cm}^{-1}$ $(\mathrm{C}=\mathrm{O}$ carbonyl stretching within the secondary amide $\mathrm{I}$ band), at 1541 and $1322 \mathrm{~cm}^{-1}$ (the bending vibration of

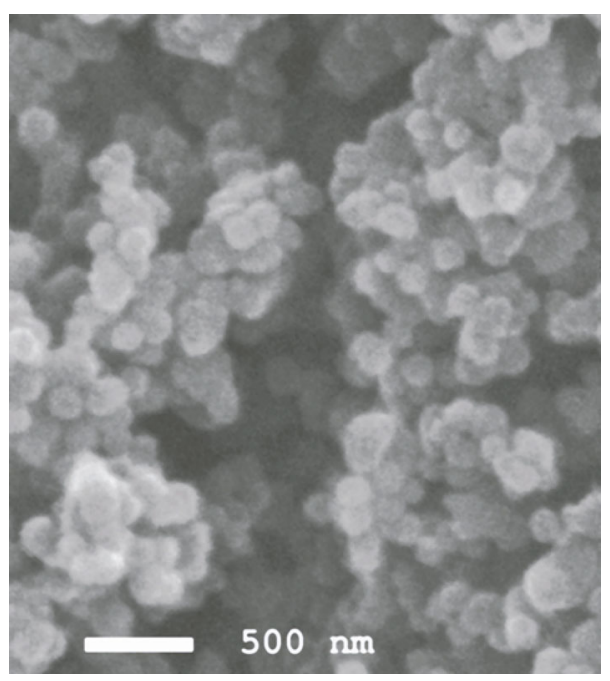

FIGURE 3: Scanning electron micrograph of nanoparticles composited from nanochitosan and nano- $\mathrm{TiO}_{2}$.

$\mathrm{N}-\mathrm{H}$ in amide II and the amide III absorption, respectively), and at $1083 \mathrm{~cm}^{-1}$ (due to $\mathrm{C}-\mathrm{O}-\mathrm{C}$ stretching).

For $\mathrm{FCt} / \mathrm{TiO}_{2}-\mathrm{NPs}$, the appeared peak at $1391 \mathrm{~cm}^{-1}$ indicates the $\mathrm{CH}_{3}$ band stretching vibrations in the nanocomposite $[32,33]$, and the $\mathrm{TiO}_{2}-\mathrm{NP}$ incorporation had obvious impact on the intensities of characteristic peaks (Figure 2, Cts/ $/ \mathrm{TiO}_{2}$-NPs).

The nanocomposite spectrum displayed many characteristic bands and peaks from both FCt-NPs and $\mathrm{TiO}_{2}-\mathrm{NPs}$ (designated by the vertical lines on the figure). The Ti-O band within $550-700 \mathrm{~cm}^{-1}$ range designated $\mathrm{TiO}_{2}$ immobilization onto FCt matrix [42]. Compared with pure FCt-NP spectrum, many corresponding bands to amino, hydroxyl, and amide groups were shifted in $\mathrm{FCt} / \mathrm{TiO}_{2}-\mathrm{NP}$ composite spectrum; these IR shifts confirmed the interaction between both the conjugated NPs.

The composited $\mathrm{FCt} / \mathrm{TiO}_{2}-\mathrm{NP}$ microstructure and morphology were elucidated using SEM imaging (Figure 3); they appeared with homogenized spherical shapes with some aggregation due to polymer collapse. The $\mathrm{TiO}_{2}-\mathrm{NPs}$ were mostly capped with FCt-NPs and composed uniform mixtures, as was formerly reported [33, 42]. The low aggregate size in the nanocomposites is assumingly attributive to the organic nature of FCt that could hinder the aggregation of $\mathrm{TiO}_{2}$-NPs [43].

3.4. Release Pattern of $\mathrm{TiO}_{2}-\mathrm{NPs}$ from FCt-NP Nanocomposite. The release pattern of $\mathrm{TiO}_{2}-\mathrm{NPs}$ from their nanocomposite with FCt-NPs is performed throughout $180 \mathrm{~min}$ releasing time (Figure 4); the released $\mathrm{TiO}_{2}$ amounts from the nanocomposite were $31.2 \%$ after the first hour and reached $50.2 \%$ at the experiment end. The release pattern $\mathrm{TiO}_{2}-\mathrm{NPs}$ and its influence with stirring time was indicated from other colloids, cream, and sunscreen $[44,45]$; the $\mathrm{TiO}_{2}$ release percentages in these studies were higher than the obtained values in a current study, which indicate the high capability of FCt-NPs for entrapping and capping the $\mathrm{TiO}_{2}$-NPs and preventing them from disintegration. The main suggested factor for $\mathrm{TiO}_{2}-\mathrm{NP}$ 


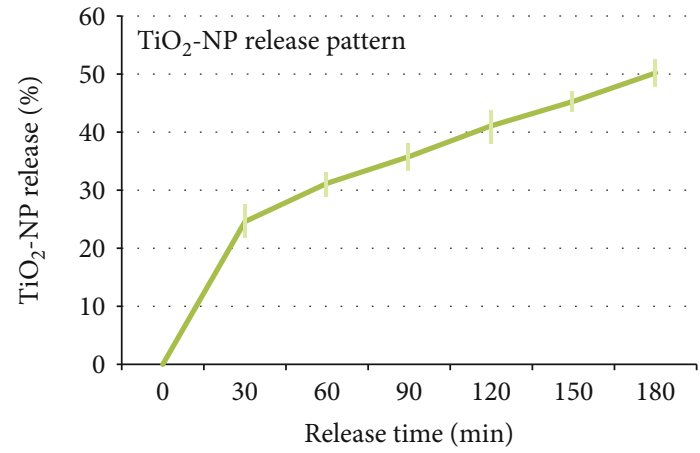

Figure 4: The release pattern of $\mathrm{TiO}_{2}$-NPs from their nanocomposite with nanochitosan. ${ }^{*}$ Values are mean of triplicates with the illustrated error bars.

releasing could be the degradation of FCt-based film that assists the liberation of capped metal NPs.

The controlled release of $\mathrm{TiO}_{2}$-NPs, via their conjugation with FCt-NPs, is highly important for sustained fortification of plants with $\mathrm{Ti}$ ions for longer times and required concentrations $[12,46]$.

Many patents and inventions advocated $\mathrm{TiO}_{2}-\mathrm{NP}$ applications in plant fertilization purposes, either as liquid or colloidal compositions, which could promote foliar and root growth $[6,12]$; this supports the potential application of current fabricated $\mathrm{FCt} / \mathrm{TiO}_{2}$ - $\mathrm{NP}$ composites as sustained and controlled source of $\mathrm{Ti}$ ions for plant fertilization. In addition, the controlled release of $\mathrm{Ti}$, via incorporation in $\mathrm{FCt} / \mathrm{TiO}_{2}-\mathrm{NP}$ composites, could be highly beneficial for providing the plant with this essential element without its potential toxicity at higher doses [6]. The sustained release of $\mathrm{TiO}_{2}$-NPs could, additionally, provide advantageous long-lasting antimicrobial potentiality against the pathogenic microbial communities in treated soils $[2,3]$, whereas the application of $\mathrm{TiO}_{2}-\mathrm{NP}$ fertilizers was stated to have no effect on the community structure of either rhizobia or arbuscular mycorrhizal fungi that colonized plant roots, at any concentration [47]. This expected antimicrobial power from FCt/ $\mathrm{TiO}_{2}$-NPs could have influential consequences to protect soils and plants from pathogenic microbes.

\subsection{Hydrolytic Degradation Patterns of Nanocomposed Films.} The hydrolytic degradation patterns of composed films from $\mathrm{FCt}-\mathrm{NPs}$ and $\mathrm{FCt} / \mathrm{TiO}_{2}$-NPs are illustrated in Figure 5. Both NPs-based films were gradually degraded and lost their weights with prolongation of experiments; the $\mathrm{FCt} / \mathrm{TiO}_{2}-$ NPs-based film showed faster degradation than FCt-NPsbased film. The $\mathrm{FCt} / \mathrm{TiO}_{2}$-NP film completely degraded after $7 \mathrm{~h}$ of treatment, whereas the FCt-NPs film lost $67.4 \%$ of its weight at this time and its degradation percentage was 93.2\% after $10 \mathrm{~h}$ of treatment (Figure 5).

The degradation rate of $\mathrm{FCt} / \mathrm{TiO}_{2}$-NPs-based film could be correlated with $\mathrm{TiO}_{2}-\mathrm{NP}$ release from this nanocomposite, as the degradation rate was $42.8 \%$ after $3 \mathrm{~h}$ and the liberated $\mathrm{TiO}_{2}$-NPs was slightly higher than this percentage, at the same time. The excess liberated amounts from the nanopolymer composite are assumingly due to decreased electrostatic

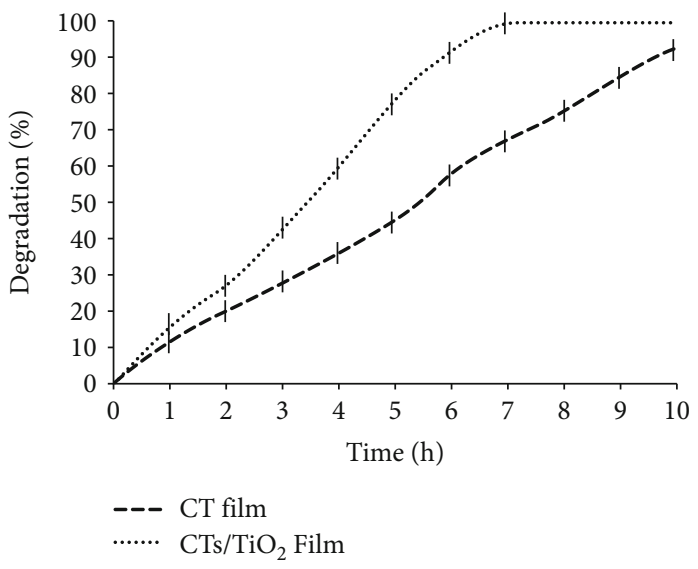

Figure 5: The hydrodegradation patterns of prepared films from nanochitosan (CTs film) and its composite with $\mathrm{TiO}_{2}-\mathrm{NPs}$ $\left(\mathrm{CTs} / \mathrm{TiO}_{2}\right.$ film). ${ }^{*}$ Values are mean of triplicates with the illustrated error bars.

bonds between them and electron exchanges within the nanocomposite after its hydrolytic destabilization [36, 48].

Theoretically, $\mathrm{TiO}_{2}$-containing films are assumed to have a slower rate of degradation because of the antimicrobial action of $\mathrm{TiO}_{2}-\mathrm{NPs}$ that can retard microbial degradation of composited films [48], but the composed films from the $\mathrm{PLA} / \mathrm{TiO}_{2}$ composite exhibited greatly higher hydrolytic degradation rate than films from PLA resin [36]; this increased degradability of $\mathrm{TiO}_{2}$-incorporated films was attributed to the photodegradation properties of $\mathrm{TiO}_{2}-\mathrm{NPs}$, which is activated by NP exposure to UV and visible lights and lead to faster degradation of their composited films $[36,49]$. These harmonized results with ours could advocate the incorporation of $\mathrm{TiO}_{2}$-NPs into nanocomposites to control their hydrodegradability [42]. Additionally, the improvement in the biodegradability of chitosan/ $/ \mathrm{TiO}_{2}$ hybrid composite was reported as $\mathrm{a} \mathrm{TiO}_{2}$ dose dependent $[31,48]$, which advocates further experiments to specify the exact optimum $\mathrm{TiO}_{2}-\mathrm{NPs}$ for controlling films' degradability.

However, the fabricated nanocomposite here from FCt/ $\mathrm{TiO}_{2}$-NPs could have elevated potentiality for application as liquid spray for foliar feeding or as powder for soil amendment [50].

\section{Conclusion}

The phytosynthesis of $\mathrm{TiO}_{2}$-NPs was innovatively achieved using PRE and their nanocomposites with FCt-NPs had homogenous organization and miniature sizes. The nanocomposite had a faster hydrodegradability which resulted from $\mathrm{TiO}_{2}-\mathrm{NP}$ addition, which advocates its application as liquid spray for foliar feeding or as powder for soil amendment. These formulated nanocomposites could be possible candidates for application as nanofertilizers to deliver $\mathrm{TiO}_{2}-$ NPs into plants in a controlled manner. However, more investigations are required to judge the practical application of $\mathrm{FCt} / \mathrm{TiO}_{2}-\mathrm{NP}$ nanocomposite as a fertilizer. 


\section{Data Availability}

The datasets generated during and/or analyzed during the current study are available from the corresponding author on reasonable request.

\section{Ethical Approval}

This article does not contain any studies with human or animal subjects.

\section{Conflicts of Interest}

The author declares that he has no known competing financial interests or personal relationships that could have appeared to influence the work reported in this paper.

\section{Acknowledgments}

This project was funded by the DSR (Deanship of Scientific Research at King Abdulaziz University, Jeddah, KSA) under grant number G-353-662-1440. The authors, therefore, acknowledge with thanks DSR for the technical and financial support.

\section{Supplementary Materials}

The supplementary file includes the graphical abstract. (Supplementary Materials)

\section{References}

[1] F. Ghooshchi, "Influence of titanium and bio-fertilizers on some agronomic and physiological attributes of triticale exposed to cadmium stress," Global NEST Journal, vol. 19, no. 3, pp. 458-463, 2017.

[2] S. Yaghoubi, W. Schwietert, and J. P. Mccue, "Biological roles of titanium," Biological Trace Element Research, vol. 78, no. 1-3, pp. 205-217, 2000.

[3] X. Zhang, G. Xiao, Y. Wang, Y. Zhao, H. Su, and T. Tan, "Preparation of chitosan- $\mathrm{TiO}_{2}$ composite film with efficient antimicrobial activities under visible light for food packaging applications," Carbohydrate Polymers, vol. 169, pp. 101-107, 2017.

[4] E. Morteza, P. Moaveni, H. A. Farahani, and M. Kiyani, "Study of photosynthetic pigments changes of maize (Zea mays L.) under nano $\mathrm{Tio}_{2}$ spraying at various growth stages," Springerplus, vol. 2, no. 1, pp. 1-5, 2013.

[5] S. C. Capaldi Arruda, A. L. Diniz Silva, R. Moretto Galazzi, R. Antunes Azevedo, and M. A. Zezzi Arruda, "Nanoparticles applied to plant science: a review," Talanta, vol. 131, pp. 693705, 2015.

[6] S. Lyu, X. Wei, J. Chen, C. Wang, X. Wang, and D. Pan, "Titanium as a beneficial element for crop production," Frontiers in Plant Science, vol. 8, 2017.

[7] M. R. Naderi and A. Danesh-Shahraki, "Nanofertilizers and their roles in sustainable agriculture," International Journal of Agriculture and Crop Sciences, vol. 5, no. 19, pp. 22292232, 2013.

[8] G. N. Rameshaiah, S. Jpallavi, and S. Shabnam, "Nano fertilizers and nano sensors-an attempt for developing smart agriculture," International Journal of Engineering Research and General Science, vol. 3, no. 1, pp. 314-320, 2015.

[9] S. Ahmed, M. Ahmad, B. L. Swami, and S. Ikram, "A review on plants extract mediated synthesis of silver nanoparticles for antimicrobial applications: a green expertise," Journal of Advanced Research, vol. 7, no. 1, pp. 17-28, 2016.

[10] M. Mandeh, M. Omidi, and M. Rahaie, "In vitro influences of $\mathrm{TiO}_{2}$ nanoparticles on barley (Hordeum vulgare L.) tissue culture," Biological Trace Element Research, vol. 150, no. 1-3, pp. 376-380, 2012.

[11] U. Song, M. Shin, G. Lee, J. Roh, Y. Kim, and E. J. Lee, "Functional analysis of $\mathrm{TiO}_{2}$ nanoparticle toxicity in three plant species," Biological Trace Element Research, vol. 155, no. 1, pp. 93-103, 2013.

[12] M. Janmohammadi, N. Sabaghnia, S. Dashti, and M. Nouraein, "Investigation of foliar application of nanomicronutrientfertilizers and nano-titanium dioxide on some traits of barley," Biologija, vol. 62, no. 2, pp. 148-156, 2016.

[13] V. Patidar and P. Jain, "Green Synthesis of $\mathrm{TiO}_{2}$ Nanoparticle Using Moringa Oleifera Leaf Extract," International Research Journal of Engineering and Technology, vol. 4, no. 3, pp. 470473, 2017.

[14] S. P. Goutam, G. Saxena, V. Singh, A. K. Yadav, R. N. Bharagava, and K. B. Thapa, "Green synthesis of $\mathrm{TiO}_{2}$ nanoparticles using leaf extract of Jatropha curcas L. for photocatalytic degradation of tannery wastewater," Chemical Engineering Journal, vol. 336, pp. 386-396, 2018.

[15] M. Nadeem, D. Tungmunnithum, C. Hano et al., "The current trends in the green syntheses of titanium oxide nanoparticles and their applications," Green Chemistry Letters and Reviews, vol. 11, no. 4, pp. 492-502, 2018.

[16] P. Makvandi, G. W. Ali, F. Della Sala, W. I. Abdel-Fattah, and A. Borzacchiello, "Biosynthesis and characterization of antibacterial thermosensitive hydrogels based on corn silk extract, hyaluronic acid and nanosilver for potential wound healing," Carbohydrate Polymers, vol. 223, article 115023, 2019.

[17] P. Makvandi, G. W. Ali, F. Della Sala, W. I. Abdel-Fattah, and A. Borzacchiello, "Hyaluronic acid/corn silk extract based injectable nanocomposite: a biomimetic antibacterial scaffold for bone tissue regeneration," Materials Science and Engineering: $C$, vol. 107, article 110195, 2020.

[18] E. N. Zare, P. Makvandi, A. Borzacchiello, F. R. Tay, B. Ashtari, and V. V. T. Padil, "Antimicrobial gum bio-based nanocomposites and their industrial and biomedical applications," Chemical Communications, vol. 55, no. 99, pp. 14871-14885, 2019.

[19] R. Jamaledin, C. K. Y. Yiu, E. N. Zare et al., "Advances in antimicrobial microneedle patches for combating infections," Advanced Materials, vol. 32, no. 33, article 2002129, 2020.

[20] C. Y. Wang, P. Makvandi, E. N. Zare, F. R. Tay, and L. N. Niu, "Advances in antimicrobial organic and inorganic nanocompounds in biomedicine," Advanced Therapeutics, vol. 3, no. 8, article 2000024, 2020.

[21] P. Makvandi, C. Y. Wang, E. N. Zare, A. Borzacchiello, L. N. Niu, and F. R. Tay, "Metal-based nanomaterials in biomedical applications: antimicrobial activity and cytotoxicity aspects," Advanced Functional Materials, vol. 30, no. 22, article 1910021, 2020.

[22] H. Yang, Y. Y. Ren, T. Wang, and C. Wang, "Preparation and antibacterial activities of $\mathrm{Ag} / \mathrm{Ag}+/ \mathrm{Ag} 3+$ nanoparticle composites 
made by pomegranate (Punica granatum) rind extract," Results in Physics, vol. 6, pp. 299-304, 2016.

[23] F. Mohamed, M. Rabia, and M. Shaban, "Synthesis and characterization of biogenic iron oxides of different nanomorphologies from pomegranate peels for efficient solar hydrogen production," Journal of Materials Research and Technology, vol. 9, no. 3, pp. 4255-4271, 2020.

[24] S. N. A. Mohamad Sukri, K. Shameli, M. Mei-Theng Wong, S. Y. Teow, J. Chew, and N. A. Ismail, "Cytotoxicity and antibacterial activities of plant-mediated synthesized zinc oxide $(\mathrm{ZnO})$ nanoparticles using Punica granatum (pomegranate) fruit peels extract," Journal of Molecular Structure, vol. 1189, pp. 57-65, 2019.

[25] A. Ali and S. Ahmed, "A review on chitosan and its nanocomposites in drug delivery," International Journal of Biological Macromolecules, vol. 109, pp. 273-286, 2018.

[26] A. A. Tayel, S. A. Ibrahim, M. A. al-Saman, and S. H. Moussa, "Production of fungal chitosan from date wastes and its application as a biopreservative for minced meat," International Journal of Biological Macromolecules, vol. 69, pp. 471-475, 2014.

[27] A. A. Tayel, "Microbial chitosan as a biopreservative for fish sausages," International Journal of Biological Macromolecules, vol. 93, no. Part A, pp. 41-46, 2016.

[28] A. A. Tayel, M. M. Gharieb, H. R. Zaki, and N. M. Elguindy, "Bio-clarification of water from heavy metals and microbial effluence using fungal chitosan," International Journal of Biological Macromolecules, vol. 83, pp. 277-281, 2016.

[29] S. Alsharari, A. A. Tayel, and S. H. Moussa, "Soil emendation with nano-fungal chitosan for heavy metals biosorption," International Journal of Biological Macromolecules, vol. 118, no. Part B, pp. 2265-2268, 2018.

[30] A. I. Alalawy, H. A. El Rabey, F. M. Almutairi et al., "Effectual anticancer potentiality of loaded bee venom onto fungal chitosan nanoparticles," International Journal of Polymer Science, vol. 2020, Article ID 2785304, 9 pages, 2020.

[31] L. M. Anaya-Esparza, J. M. Ruvalcaba-Gómez, C. I. Maytorena-Verdugo et al., "Chitosan- $\mathrm{TiO}_{2}$ : a versatile hybrid composite," Materials, vol. 13, no. 4, 2020.

[32] F. A. Al-Sagheer and S. Merchant, "Visco-elastic properties of chitosan-titania nano-composites," Carbohydrate Polymers, vol. 85, no. 2, pp. 356-362, 2011.

[33] K. Kavitha, M. Prabhu, V. Rajendran, P. Manivasankan, P. Prabu, and T. Jayakumar, "Optimization of nano-titania and titania-chitosan nanocomposite to enhance biocompatibility," Current Nanoscience, vol. 9, no. 3, pp. 308-317, 2013.

[34] A. A. Tayel, W. F. El-Tras, S. H. Moussa, and S. M. El-Sabbagh, "Surface decontamination and quality enhancement in meat steaks using plant extracts as natural biopreservatives," Foodborne Pathogens and Disease, vol. 9, no. 8, pp. 755-761, 2012.

[35] M. d. G. A. Korn, A. C. Ferreira, A. C. S. Costa, J. A. Nóbrega, and C. R. Silva, "Comparison of decomposition procedures for analysis of titanium dioxide using inductively coupled plasma optical emission spectrometry," Microchemical Journal, vol. 71, no. 1, pp. 41-48, 2002.

[36] A. Buzarovska and A. Grozdanov, "Biodegradable poly(L-lactic acid) $/ \mathrm{TiO}_{2}$ nanocomposites: Thermal properties and degradation," Journal of Applied Polymer Science, vol. 123, no. 4, pp. 2187-2193, 2012.

[37] B. Singh, J. P. Singh, A. Kaur, and N. Singh, "Phenolic compounds as beneficial phytochemicals in pomegranate (Punica granatum L.) peel: A review," Food Chemistry, vol. 261, pp. 75-86, 2018.

[38] N. Ahmad, S. Sharma, and R. Rai, "Rapid green synthesis of silver and gold nanoparticles using peels of Punica granatum," Advanced Materials Letters, vol. 3, no. 5, pp. 376-380, 2012.

[39] H. A. el Rabey, F. M. Almutairi, A. I. Alalawy et al., "Augmented control of drug-resistant Candida spp. via fluconazole loading into fungal chitosan nanoparticles," International Journal of Biological Macromolecules, vol. 141, pp. 511-516, 2019.

[40] P. Manivasakan, V. Rajendran, P. R. Rauta et al., "Effect of $\mathrm{TiO}_{2}$ nanoparticles on properties of silica refractory," Journal of the American Ceramic Society, vol. 93, no. 8, pp. 2236$2243,2010$.

[41] A. Jamil, T. H. Bokhari, T. Javed et al., "Photocatalytic degradation of disperse dye Violet-26 using $\mathrm{TiO} 2$ and $\mathrm{ZnO}$ nanomaterials and process variable optimization," Journal of Materials Research and Technology, vol. 9, no. 1, pp. 11191128, 2020.

[42] L. Yang, L. Jiang, D. Hu et al., "Swelling induced regeneration of $\mathrm{TiO}_{2}$-impregnated chitosan adsorbents under visible light," Carbohydrate Polymer, vol. 140, pp. 433-441, 2016.

[43] C. Kim, J. Lee, and S. Lee, " $\mathrm{TiO}_{2}$ nanoparticle sorption to sand in the presence of natural organic matter," Environmental Earth Sciences, vol. 73, no. 9, pp. 5585-5591, 2015.

[44] C. Botta, J. Labille, M. Auffan et al., " $\mathrm{TiO}_{2}$-based nanoparticles released in water from commercialized sunscreens in a lifecycle perspective: structures and quantities," Environmental Pollution, vol. 159, no. 6, pp. 1543-1550, 2011.

[45] S. Jeon, E. Kim, J. Lee, and S. Lee, "Potential risks of TiO2 and $\mathrm{ZnO}$ nanoparticles released from sunscreens into outdoor swimming pools," Journal of Hazardous Materials, vol. 317, no. 5, pp. 312-318, 2016.

[46] S. Compant, A. Samad, H. Faist, and A. Sessitsch, "A review on the plant microbiome: ecology, functions, and emerging trends in microbial application," Journal of Advanced Research, vol. 19, pp. 29-37, 2019.

[47] D. J. Burke, N. Pietrasiak, S. F. Situ et al., "Iron oxide and titanium dioxide nanoparticle effects on plant performance and root associated microbes," International Journal of Molecular Sciences, vol. 16, no. 10, pp. 23630-23650, 2015.

[48] I. Kustiningsih, A. Ridwan, D. Abriyani, M. Syairazy, T. Kurniawan, and D. R. Barleany, "Development of chitosan- $\mathrm{TiO}_{2}$ nanocomposite for packaging film and its ability to inactive Staphylococcus aureus," Oriental Journal of Chemistry, vol. 35, no. 3, pp. 1132-1137, 2019.

[49] N. Nakayama and T. Hayashi, "Preparation and characterization of poly(L-lactic acid)/ $/ \mathrm{TiO}_{2}$ nanoparticle nanocomposite films with high transparency and efficient photodegradability," Polymer Degradation and Stability, vol. 92, no. 7, pp. 12551264, 2007.

[50] L. Bellani, G. Siracusa, L. Giorgetti et al., " $\mathrm{TiO}_{2}$ nanoparticles in a biosolid-amended soil and their implication in soil nutrients, microorganisms and Pisum sativum nutrition," Ecotoxicology and Environmental Safety, vol. 190, article 110095, 2020 . 